\title{
Engin marktæk tengsl offitu og lifunar eftir kransæðahjáveituaðgerð
}

\author{
Pórdís Porkelsdóttir ${ }^{1}$ \\ Hera Jóhannesdóttir ${ }^{2}$ \\ Linda Ósk Árnadóttir ${ }^{2}$ \\ Jónas Aðalsteinsson ${ }^{6}$ \\ Helga Rún Garðarsdóttir ${ }^{3}$ \\ Daði Helgason ${ }^{3}$ \\ Tómas Andri Axelsson² \\ Sólveig Helgadóttir ${ }^{5}$ \\ Alexandra Aldís Heimisdóttir ${ }^{1}$ \\ Martin Ingi Sigurðsson ${ }^{1,4}$ \\ Tómas Guðbjartsson ${ }^{1,2}$
}

'Læknadeild Háskóla Íslands, ${ }^{2} H$ jarta- og lungnaskurðdeild, ${ }^{3}$ Lyflækningasvið og ${ }^{4}$ Svæfingaog giörgæsludeild Landspítala háskólasjúkrahúss, ${ }^{5}$ Svæfinga- og giörgæsludeild Akademíska hjáskólasjúkrahússins í Uppsölum, ${ }^{6}$ Lyf- og húđlækningasvið háskólasjúkrahúss Connecticut

Fyrirspurnum svarar Tómas Guðbjartsson tomasgudbjartsson@hotmail.com

\section{Inngangur}

Einn af áhættupáttum kransæðasjúkdóms er offita en hún er vaxandi vandamál víðast hvar í heiminum..$^{1-3}$ Offita er oftast metin með líkamspyngdarstuðli (LPS) sem reiknaður er út frá pyngd og hæð samkvæmt formúlunni $\mathrm{kg} / \mathrm{m}^{2}$. Alpjóðaheilbrigðismálastofnunin (WHO) skiptir LPS í nokkra flokka og er talað um of pyngd pegar LPS er á bilinu $25-29,9 \mathrm{~kg} / \mathrm{m}^{2}$ og offitu pegar LPS $\geq 30 \mathrm{~kg} / \mathrm{m}^{2}$, en síðarnefnda flokknum er síðan skipt upp í prennt; Flokk I: LPS 30-34,9 $\mathrm{kg} / \mathrm{m}^{2}$, flokk II: $35-39,9 \mathrm{~kg} / \mathrm{m}^{2}$ og flokk III: $\geq 40 \mathrm{~kg} / \mathrm{m}^{2}{ }^{4}$ Samkvæmt pessari flokkun pjást 23\% fullorðinna Íslendinga af offitu og er hlutfallið pað hæsta á Norðurlöndum. ${ }^{5}$ Einnig er áhyggjuefni hérlendis hversu mikið offita hefur aukist meðal barna og unglinga ${ }^{6}$ pví henni fylgja oft sjúkdómar síðar á ævinni eins og hækkaður blóðprýstingur, blóðfituröskun og sykursýki sem allt eru sjálfstæðir áhættupættir kransæðasjúkdóms, líkt og offita.--9 Sjúklingar sem pjást af offitu próa oftar og fyrr á ævinni með sér alvarlegan kransæðasjúkdóm ${ }^{10-12}$ sem oft einkennist af marktækum prengingum í öllum helstu kransæðum (einnig kallað priggja æða sjúkdómur) eða í vinstri höfuðstofni. Er pá yfirleitt mælt með kransæðahjáveituaðgerð, óháð líkamspyngd sjúklings. ${ }^{13,14}$

\begin{abstract}
Á G R I P
Inngangur: Markmið rannsóknarinnar var að kanna langtímaárangur kransæðahjáveituaðgerða hjá sjúklingum sem pjást af offitu. Efniviður og aðferðir: Afturskyggn rannsókn á 1698 sjúklingum sem gengust undir kransæðahjáveituaðgerð á Landspítala 2001-2013. Sjúklingunum var skipt upp í fjóra hópa eftir líkamspyngdarstuð̋li (LPS); i) kjörpyngd=18,5-24,9 kg/m² ( $\mathrm{n}=393$ ), ii) ofbyngd=25-29,9 kg/ $\mathrm{m}^{2}(\mathrm{n}=811)$, iii) offita $=30-34,9 \mathrm{~kg} / \mathrm{m}^{2}(\mathrm{n}=388)$ og iv) mikil offita $\geq 35$ $\mathrm{kg} / \mathrm{m}^{2}(\mathrm{n}=113)$. Sjö sjúklingar með LPS $<18,5 \mathrm{~kg} / \mathrm{m}^{2}$ voru útilokaðir úr rannsókninni. Snemmkomnir fylgikvillar og 30 daga dánartíoni voru skrád auk eftirfarandi langvinnra fylgikvilla: hjartaáfalls, heilablóđfalls, parfar á endurhjáveituađgerð, kransæđavíkkunar med eða án kransæðastoðnets og dauð̃a (major adverse cardiac and cerebrovascular events, MACCE). Hóparnir voru bornir saman með áherslu á langtímalifun og MACCE-fría lifun (Kaplan-Meier) og forspárpættir lifunar fundnir með Cox-aðhvarfsgreiningu. Meðaltal eftirfylgdar var 5,6 ár.

Niðurstöður: Sjúklingar með mikla offitu reyndust vera að meðaltali 6,0 árum yngri en sjúklingar í kjörpyngd, hlutfall karla var hærra og peir höfðu oftar áhættubætti kransæðasjúkdóms, auk bess sem EuroSCORE II peirra var lægra (1,6 sbr. 2,7, $p=0,002)$. Tíoni alvarlegra snemmkominna fylgikvilla og 30 daga dánartí̋ni (2\%) var sambærileg milli hópa, líkt og langtímalifun (í kringum 90\% eftir 5 ár, log-rank próf, $p=0,088$ ) og lifun án MACCE (í kringum $80 \%$ eftir 5 ár, log-rank próf, $\mathrm{p}=0,7$ ). Í aðhvarfsgreiningu reyndist LPS hvorki sjálfstæður forspárpáttur langtímalifunar (HH: 0,98 95\% ÖB: 0,95-1,01) né MACCE-frírrar lifunar (HH: 1,0 ÖB: 0,98-1,02).

Ályktun: Sjúklingar með offitu sem gangast undir kransæðahjáveitu á Landspítalanum eru yngri en með fleiri áhættupætti kransæðasjúkdóms en samanburðarhópur. Líkamspyngdarstuðull spáir pó hvorki fyrir um langtímalifun né tíóni fylgikvilla. Árangur kransæðahjáveituaơgerða hjá sjúklingum sem bjást af offitu er góður hér á landi.
\end{abstract}

https://doi.org/10.17992//bl.2019.0708.240

Offita hefur löngum verið tengd lakari árangri skurðaðgerða og hærri tíðni fylgikvilla, sér í lagi skurðsýkinga. ${ }^{15,16}$ Auk pess eru aðgerðir á offeitum oft tæknilega erfiðari en á grönnum einstaklingum og aðgerðartími peirra pví lengri. ${ }^{17-19}$ Engu að síður hefur fjöldi erlendra rannsókna sýnt að árangur ýmissa skurðaðgerða hjá sjúklingum með offitu er oft sambærilegur og hjá sjúklingum í kjörpyngd, par með talin skammtímalifun. ${ }^{20}$ Petta kallast offitupversögn (obesity paradox) og hefur verið lýst eftir kransæðahjáveituaðgerðir hjá sjúklingum sem pjást af offitu ${ }^{20,21}$ en ekki fyrir sjúklinga með mjög háan eða mjög lágan LPS. ${ }^{22,23}$ Flestar rannsóknirnar, par á meðal íslensk rannsókn sem náði til 720 sjúklinga á Landspítala sem skornir voru á tímabilinu 2001-2006, hafa einblínt á snemmkomna fylgikvilla og 30 daga dánartíðni. ${ }^{15,24,25}$ Færri rannsóknir hafa litið á langtímaárangur og niðurstöður peirra sem birst hafa verið misvísandi hvað árangur varðar. ${ }^{26-29}$ 
Markmið pessarar rannsóknar var pví að varpa ljósi á langtímaárangur sjúklinga með mismikla offitu eftir kransæðahjáveituaðgerð og bera pá saman við sjúklinga í kjörpyngd. Sérstaklega var litið á langtíma fylgikvilla og langtímalifun auk pess sem sjálfstæðir forspárpættir langtímalifunar voru metnir.

\section{Efniviður og aðferðir}

Rannsóknin var afturskyggn og náði til 1755 sjúklinga 18 ára og eldri sem gengust undir kransæðahjáveituaðgerð eingöngu (isolated $C A B G$ ) á Landspítala frá 1. janúar 2001 til 31. desember 2013. Við rannsóknina var stuðst við gagnagrunn hjarta- og lungnaskurðdeildar, en auk pess leitað að sjúklingum í tveimur miðlægum skrám, annars vegar í aðgerðaskrá hjarta- og lungnaskurðdeildar Landspítala og hins vegar í sjúklingabókhaldi Landspítala. Par var leitað að aðgerðarnúmerum fyrir kransæðahjáveituaðgerð (FNSA00, FNSC10, FNSC20 og FNSC30) og aðgerðum par sem notuð var hjarta- og lungnavél (FZSA00 og FZSA10). Sleppa purfti 50 af 1755 einstaklingum (2,8\%) í gagnagrunninum par sem mælingar á hæð og pyngd vantaði. Sjúklingar með LPS $<18,5 \mathrm{~kg} / \mathrm{m}^{2}$ voru aðeins 7 talsins og voru peir útilokaðir úr rannsókninni, enda ekki rétt að meta svo fáa sjúklinga tölfræðilega sem sérstakan hóp. Rannsóknarpýðið samanstóð pví af 1698 sjúklingum.

Klínískar upplýsingar voru fengnar úr sjúkraskrám og aðgerðarlýsingum. Fyrir hvern sjúkling voru skráđar tæplega 130 breytur í rafræna Excel-skrá, meðal annars aldur, kyn, pyngd og hæð. LPS var reiknaður út frá pyngd og hæð fyrir aðgerð og sjúklingum skipt upp í fjóra hópa eftir LPS. Stuðst var við áðurnefnda flokkun Alpjóðaheilbrigðismálastofnunarinnar; i) kjörpyngd = $18,5-24,9 \mathrm{~kg} / \mathrm{m}^{2}(\mathrm{n}=393)$, ii) of pyngd $=25-29,9 \mathrm{~kg} / \mathrm{m}^{2}(\mathrm{n}=811)$, iii) offita $=30-34,9 \mathrm{~kg} / \mathrm{m}^{2}(\mathrm{n}=388)$ og iv) mikil offita $=\geq 35 \mathrm{~kg} / \mathrm{m}^{2}(\mathrm{n}=113){ }^{30}$ Sjúklingar með LPS $<18,5 \mathrm{~kg} / \mathrm{m}^{2}$ voru sem fyrr segir aðeins 7 talsins og var peim pví sleppt við tölfræðiúrvinnslu. Áhættupættir fyrir hjarta- og æðasjúkdóma voru skráðir, eins og háprýstingur, sykursýki, blóðfituröskun og saga um reykingar. Einnig var skráð hvort sjúklingur hafði fyrri sögu um hjarta- og æðasjúkdóma eins og hjartabilun, hjartsláttaróreglu, lokusjúkdóma eða hjartadrep. Útbreiðsla kransæðasjúkdóms var skráð samkvæmt niðurstöðu úr kransæðarpræðingu, einnig upplýsingar um útstreymisbrot vinstri slegils (left ventricular ejection fraction, LVEF) samkvæmt hjartaómskoðun fyrir aðgerð. Skert nýrnastarfsemi fyrir aðgerð var skilgreind sem gaukulsíunarhraði (GSH) undir $60 \mathrm{ml} / \mathrm{mín} / 1,73$ $\mathrm{m}^{2}$ sem samræmist skilgreiningu Kidney Disease Outcomes Quality Initiative (KDOQI) á skertri nýrnastarfsemi. ${ }^{31}$

Einnig voru færðar í grunninn upplýsingar um lyf sem sjúklingar tóku fyrir aðgerð, meðal annars blóðflöguhemjandi og blóðpynnandi lyf síðustu fimm dagana fyrir aðgerð.

Einkenni sjúklings voru metin samkvæmt NYHA (New York Heart Association) flokkun á hjartabilun og CCS (Canadian Cardiovascular Society) flokkun á hjartaöng. ${ }^{32,33}$ EuroSCORE (European System for Cardiac Operative Risk Evaluation) II var reiknað út fyrir alla sjúklingana. ${ }^{34}$

Skráð var hvort notuð var hjarta- og lungnavél (HLV) eða hvort aðgerðin var gerð á sláandi hjarta. Heildaraðgerðartími var skráður í mínútum, einnig tangartími og tími á hjarta- og lungnavél fyrir sjúklinga sem gengust undir aðgerð á HLV. Fjöldi fjaræða- tenginga á kransæðar (distal anastomoses) var skráður og hvort vinstri innri brjóstholsslagæð (left internal mammary artery, LIMA) var notuð. Blæðing í brjóstholskera fyrstu 24 klst. eftir aðgerð var skráð í ml sem og fjöldi eininga rauðkornapykknis sem sjúklingi var gefið í eða eftir aðgerð og hvort pörf hafi verið á ósæðardælu (intra-aortic balloon pump, IABP) í eða eftir aðgerð. Legutími á gjörgæslu sem og heildarlegutími voru skráðir í dögum.

Fylgikvillum var skipt í snemmkomna fylgikvilla og langtíma fylgikvilla. Snemmkomnir fylgikvillar voru skilgreindir sem fylgikvillar sem greindust innan 30 daga frá aðgerð og var peim skipt í minniháttar og alvarlega fylgikvilla. Gáttatif/gáttaflökt, aftöppun á fleiðruvökva, yfirborðssýking í skurðsári, lungnabólga, pvagfærasýking töldust til minniháttar fylgikvilla. Heilablóðfall, fjöllíffærabilun (multiorgan failure), djúp sýking í bringubeinsskurði (deep sternal wound infection), bringubeinslos, bráður nýrnaskaði af flokki 3 og enduraðgerð vegna blæðingar töldust til alvarlegra fylgikvilla. Einnig var blóðpurrð í hjartavöðva talin með alvarlegum fylgikvillum en hún var skilgreind sem nýtilkomnar ST-hækkanir eða nýtilkomið vinstra greinrof á hjartarafriti ásamt hækkun á CKMB-hjartaensíminu yfir $70 \mu \mathrm{g} / \mathrm{L}$. Stuðst var við skilgreiningu Kidney Disease Improving Global Outcomes (KDIGO) til að meta bráðan nýrnaskaða og var miðað við flokk 3, pað er preföld aukning á kreatínín-gildi frá grunngildi, aukning á Se-kreatinín-gildi í $\geq 354 \mu \mathrm{mol} 4 / \mathrm{L}$ eða pörf á bráðri skilun. ${ }^{35}$ Skurðdauði (operative mortality) var skilgreindur sem dauði innan 30 daga frá aðgerð.

Leitað var að langtíma fylgikvillum sem tengdust hjarta- og æðakerfinu með pví að skoða allar endurkomur og endurinnlagnir sjúklinga á Landspítala í Sögu, sjúkraskrárkerfi spítalans, fram til 1. júlí 2014. Einnig var farið yfir endurinnlagnir á sjúkrastofnanir á landsbyggðinni og farið yfir allar hjartapræðingar í gagnagrunni hjartapræðingadeildar Landspítala. Langtíma fylgikvillar voru hjartaáfall, heilablóðfall, endurkransæðavíkkun, endurkransæðahjáveituaðgerð og dauði. Pessir endapunktar voru teknir saman í sameiginlegan endapunkt, sem kallast MACCE (major adverse cardiac and cerebrovascular event) og er notaður í sambærilegum erlendum rannsóknum. ${ }^{36}$

Upplýsingar um langtíma fylgikvilla fengust úr sjúkraskrám í öllum helstu heilbrigðisumdæmum landsins og eftirfylgd miðaðist við 1. júlí 2014.

\section{Tölfræðiúrvinnsla}

Upplýsingar voru skráðar í tölvuforritið Excel. Tölfræðiúrvinnsla var gerð í tölfræðiforritinu R, útgáfu 3.3.2 (R foundation for Statistical Computing, Vín, Austuríki). Talnabreytur og flokkabreytur voru bornar saman með tilliti til líkamspyngdarstuðuls. Marktækni milli hópanna fjögurra og milli einstakra hópa var metin með kí-kvaðrat prófi, Fischer exact prófi eða ANOVA-prófi. Langtímalifun og MACCE-frí lifun var metin með aðferð KaplanMeier. Samanburður á lifun hópa var gerður með log-rank prófi. Sjálfstæðir forspárpættir lifunar og MACCE-frírrar lifunar voru ákvarðaðir með Cox-aðhvarfsgreiningu (Cox regression analysis). Inn í upphaflega líkanið voru teknar pær breytur sem skráðar voru í gagnagrunninn og höfðu p-gildi <0,1 í einpátta Cox-aðhvarfsgreiningu. Pær breytur voru aldur, kyn, aðgerðarár, EuroSCORE II, brjóstverkir á stigi 4 á CCS skalanum, notkun blóðfitulækk- 
Tafla I. Aldursdreifing, kynjaskipting og áhættupættir kransæđasjúkdóms hjá sjúklingum sem gengust undir kranæðahjáveituaðgerð á Íslandi 2001-2013, skipt i fjóra hópa eftir likamspyngdarstuðli. Einnig er sýndur samanburður á EuroSCORE II, einkennum, ýmsum bakgrunnspáttum og lyfjatöku fyrir aðgerð eftir líkamspyngdarhópum. Gefinn er upp fjöldi (\%) eða meðaltal með staðalfráviki.

\begin{tabular}{|c|c|c|c|c|c|c|}
\hline & $\begin{array}{c}\text { Alls } \\
(n=1698)\end{array}$ & $\begin{array}{c}\text { Kjörpyngd } \\
(\mathrm{n}=386)\end{array}$ & $\begin{array}{l}\text { Ofpyngd } \\
(n=811)\end{array}$ & $\begin{array}{c}\text { Offita } \\
(n=388)\end{array}$ & $\begin{array}{l}\text { Mikil offita } \\
\quad(n=113)\end{array}$ & p-gildi \\
\hline Aldur & $66 \pm 9,4$ & $67 \pm 10$ & $66 \pm 9$ & $65 \pm 9$ & $61 \pm 9$ & $<0,001$ \\
\hline Karlkyn & $1388(82)$ & $300(78)$ & $687(85)$ & $315(81)$ & $86(76)$ & 0,007 \\
\hline \multicolumn{7}{|l|}{ Áhættupættir kransæðasjúkdóms } \\
\hline Háprýstingur & $1102(65)$ & $213(56)$ & $530(66)$ & $266(68)$ & $93(82)$ & $<0,001$ \\
\hline Sykursýki & $271(16)$ & $39(11)$ & $116(14)$ & $75(19)$ & $41(37)$ & $<0,001$ \\
\hline Blóðfituröskun & $961(57)$ & $201(54)$ & $460(58)$ & $224(60)$ & $76(72)$ & 0,007 \\
\hline Saga um reykingar & $1220(72)$ & $263(68)$ & $568(70)$ & $300(77)$ & $89(79)$ & 0,006 \\
\hline Fjölskyldusaga & $884(52)$ & $193(53)$ & $431(55)$ & $198(54)$ & $62(61)$ & 0,50 \\
\hline \multicolumn{7}{|l|}{ Aðrir bakgrunns- og áhættupættir } \\
\hline EuroSCORE II & $2,2 \pm 3,3$ & $2,8 \pm 4,0$ & $2,2 \pm 3,5$ & $1,8 \pm 2,4$ & $1,6 \pm 1,3$ & $<0,001$ \\
\hline CCS flokkur 3-4 & $1287(76)$ & $277(72)$ & $619(76)$ & $298(77)$ & $93(82)$ & 0,47 \\
\hline NYHA flokkur III-IV & $763(45)$ & $172(54)$ & $359(54)$ & $174(54)$ & $58(62)$ & 0,49 \\
\hline Útfallsbrot vinstri slegils & $55 \pm 9,9$ & $55 \pm 11$ & $55 \pm 10$ & $55 \pm 9,5$ & $55 \pm 8,6$ & 0,64 \\
\hline $\begin{array}{l}\text { Priggja æða sjúkdómur / vinstri } \\
\text { höfuðstofnsprengsli }\end{array}$ & $1531(90)$ & $339(88)$ & $739(91)$ & $346(89)$ & $107(95)$ & 0,10 \\
\hline Skert nýrnastarfsemi* & $230(14)$ & $58(15)$ & $102(13)$ & $53(14)$ & $17(15)$ & 0,10 \\
\hline Langvinn lungnateppa & $117(7)$ & $32(8)$ & $48(6)$ & $32(8)$ & $5(4)$ & 0,08 \\
\hline \multicolumn{7}{|l|}{ Fyrri saga um hjarta- og æðasjúkdóma } \\
\hline Hjartaáfall & $432(25)$ & $110(28)$ & $197(24)$ & $102(26)$ & $23(20)$ & 0,33 \\
\hline Nýtilkomið gáttatif/-flökt & $171(10)$ & $42(11)$ & $77(10)$ & $39(10)$ & $13(12)$ & 0,84 \\
\hline Lokusjúkdómar & $47(3)$ & $8(2)$ & $21(3)$ & $14(4)$ & $4(4)$ & 0,56 \\
\hline Kransæðavíkkun, með/án stoðnets & $352(21)$ & $66(17)$ & $177(22)$ & $81(21)$ & $28(25)$ & 0,19 \\
\hline \multicolumn{7}{|l|}{ Lyfjagjöf fyrir aðgerð } \\
\hline Beta-blokkar & $1146(67)$ & $252(68)$ & $537(71)$ & $267(72)$ & $90(83)$ & 0,017 \\
\hline Blóðfitulækkandi statín & $1277(75)$ & $272(74)$ & $599(77)$ & $311(84)$ & $95(88)$ & $<0,001$ \\
\hline Acetýlsalisylsýra (aspírín) & $614(30)$ & $113(30)$ & $309(39)$ & $136(35)$ & $56(50)$ & $<0,001$ \\
\hline Heparin & $737(43)$ & $167(44)$ & $356(44)$ & $160(42)$ & $53(47)$ & 0,58 \\
\hline Clopidógrel & $59(4)$ & $12(3)$ & $30(3,8)$ & $11(2,8)$ & $6(5,3)$ & 0,60 \\
\hline
\end{tabular}

andi statíns og clopidógrels fyrir aðgerð, saga um sykursýki, háprýsting, langvinna lungnateppu, blóðfituröskun, skerta nýrnastarfsemi (GSH<60 ml/mín/1,73 m²) og útfallsbrot vinstri slegils. Breytur sem snéru að fyrri sögu um hjartaáfall, gáttatif/-flökt og kransæðavíkkun með eða án ísetningar stoðnets voru einnig teknar með í líkanið. Viðeigandi breytur voru settar hver inn í sitt líkan fyrir lifun og MACCE-fría lifun. Spágeta upphaflegu líkananna var síðan metin og breytur felldar út með „stepwise“ aðferð par til endanlegt módel fékkst. Marktækni miðaðist við p-gildi <0,05. Hlutfall (proportionality) breyta í líkaninu var metið með skipuninni cox.zph í R.

Öll tilskilin leyfi lágu fyrir áður en rannsóknin hófst, meðal annars frá Persónuvernd, Vísindasiðanefnd og framkvæmdastjóra lækninga á Landspítala.

\section{Niðurstöður}

Skipting sjúklinganna í LPS-flokka er sýnd í töflu I. Sjúklingar í kjörpyngd voru 386 (22\%), 811 (48\%) voru í ofpyngd, 388 með offitu (23\%) og 113 með mikla offitu (7\%). Sjúklingar með mikla offitu (LPS $>35 \mathrm{~kg} / \mathrm{m}^{2}$ ) voru að meðaltali 6 árum yngri en sjúklingar í kjörpyngd ( $p<0,001)$, en munurinn var ekki marktækur fyrir sjúklinga í kjör- og ofpyngd (Tafla I). Hlutfall karla var hæst í hópi ofpyngdar, eða $85 \%$, en í hinum hópunum var pað í kringum $78 \%$ og var munurinn aðeins marktækur milli kjörpyngdar (LPS 18,5$\left.24,9 \mathrm{~kg} / \mathrm{m}^{2}\right)$ og ofpyngdar (LPS $\left.25-29,9 \mathrm{~kg} / \mathrm{m}^{2}\right)(\mathrm{p}=0,0029)$. Hlutfall sjúklinga sem höfðu háprýsting og blóðfituröskun jókst marktækt með hækkandi LPS, en munurinn var ekki marktækur milli ofpyngdar og offitu (LPS 30-34,9 kg/m²). Svipaða sögu var að segja fyrir blóðfituröskun og sögu um reykingar en sykursýki jókst hins vegar marktækt á milli allra LPS-flokka, en 10\% sjúklinga í kjör- 
Tafla II. Aðgerðartengdir pættir, gjöf blóðhluta, legutími, minniháttar og alvarlegir fylgikvillar hjá sjúklingum sem gengust undir kransæðahjáveitu á Íslandi $2001-2013$ eftir likamspyngdarstuðli. Gefinn er upp fjöldi sjúklinga (\%) eđa meðaltal með staðalfráviki. Sjúklingar geta haft fleiri en einn fylgkvilla samtímis.

\begin{tabular}{|c|c|c|c|c|c|c|}
\hline Aðgerðartengdir pættir & Alls $(n=1698)$ & Kjörpyngd ( $n=386$ ) & Ofpyngd ( $n=811)$ & Offita $(n=388)$ & Mikil offita $(n=113)$ & p-gildi \\
\hline Aðgerð á sláandi hjarta (OPCAB) & $371(22)$ & $87(23)$ & $168(21)$ & $90(23)$ & $26(23)$ & 0,75 \\
\hline Aðgerðartími (mín) & $212 \pm 56$ & $207 \pm 52$ & $209 \pm 56$ & $219 \pm 58$ & $232 \pm 62$ & $<0,001$ \\
\hline Tangartími (mín) & $46 \pm 17$ & $45 \pm 17$ & $47 \pm 16$ & $48 \pm 21$ & $50 \pm 18$ & 0,004 \\
\hline Notkun LIMA-græðlings & $1597(94)$ & $354(92)$ & $767(95)$ & $365(94)$ & $111(98)$ & 0,047 \\
\hline Fjöldi fjærtenginga (bil) & $3,5(1-6)$ & $3,4(1-6)$ & $3,5(1-6)$ & $3,5(1-6)$ & $3,5(1-5)$ & 0,61 \\
\hline Blæðing eftir aðgerð (ml) & $983 \pm 1016$ & $1076 \pm 811$ & $957 \pm 614$ & $974 \pm 1707$ & $897 \pm 719$ & 0,09 \\
\hline Rauðkornapykkni (ein) & $2,6 \pm 5$ & $3,3 \pm 6$ & $2,6 \pm 4$ & $2,2 \pm 6$ & $2,4 \pm 5$ & 0,007 \\
\hline Minniháttar fylgikvillar & $828(49)$ & $190(49)$ & $394(48)$ & $186(48)$ & $58(51)$ & 0,93 \\
\hline Sýking í skurðsári & $176(10)$ & $39(10)$ & $72(8,9)$ & $43(11)$ & $23(20)$ & 0,003 \\
\hline Nýtilkomið gáttatif/-flökt & $566(33)$ & $129(33)$ & $282(35)$ & $125(32)$ & $30(27)$ & 0,33 \\
\hline Aftöppun fleiðruvökva & $185(11)$ & $61(16)$ & $83(10)$ & $32(8)$ & $9(8)$ & $<0,003$ \\
\hline Lungnabólga & $111(7)$ & $28(7)$ & $52(6)$ & $25(6)$ & $6(5)$ & 0,89 \\
\hline Pvagfærasýking & $58(3)$ & $12(3)$ & $24(3)$ & $17(4)$ & $5(4)$ & 0,56 \\
\hline Alvarlegir fylgikvillar & $286(17)$ & $75(19)$ & $131(16)$ & $60(16)$ & $20(18)$ & 0,45 \\
\hline Bráđur nýrnaskaði & $14(1)$ & $4(1)$ & $4(0,5)$ & $4(1)$ & $2(2)$ & 0,27 \\
\hline Miðmætisbólga & $14(1)$ & $0(0)$ & $8(1)$ & $4(1)$ & $2(2)$ & 0,08 \\
\hline Bringubeinslos & $27(2)$ & $4(1)$ & $12(1)$ & $9(2)$ & $2(2)$ & 0,51 \\
\hline Heilablóðfall & $22(1)$ & $7(2)$ & $8(1)$ & $4(1)$ & $3(3)$ & 0,29 \\
\hline Fjöllíffærabilun & $54(3)$ & $15(4)$ & $25(3)$ & $8(2)$ & $6(5)$ & 0,24 \\
\hline 30 daga dánartíðni & $40(2)$ & $12(3)$ & $17(2)$ & $9(2)$ & $2(12)$ & 0,73 \\
\hline \multicolumn{7}{|l|}{ Legutími } \\
\hline Legutími á gjörgæslu (dagar) & $1,9 \pm 3$ & $1,9 \pm 3$ & $2 \pm 3$ & $1,7 \pm 3$ & $2 \pm 3$ & 0,70 \\
\hline Heildarlegutími (dagar) & $11 \pm 8$ & $11 \pm 8$ & $11 \pm 7$ & $11 \pm 8$ & $13 \pm 13$ & 0,43 \\
\hline
\end{tabular}

pyngd höfðu sykursýki borið saman við 37\% sjúklinga með mikla offitu $(\mathrm{p}<0,001)$.

Í töflu I má sjá EuroSCORE II hópanna fjögurra, en pað lækkaði með hækkandi LPS, eða frá 2,8 fyrir sjúklinga í kjörpyngd í 1,6 hjá peim sem voru með mikla offitu $(\mathrm{p}=0,002)$. Munurinn var marktækur milli allra hópa nema við samanburð sjúklinga með offitu og mikla offitu (LPS $\left.>35 \mathrm{~kg} / \mathrm{m}^{2}\right)(\mathrm{p}=0,29)$. Tafla I sýnir einnig að einkenni sjúklinga metin með CCS- og NYHA-kvörðum voru ápekk, líkt og útfallsbrot vinstra slegils og fyrri saga um hjartasjúkdóma.

Tafla I sýnir lyf sem sjúklingar tóku fyrir aðgerð. Af sjúklingum með mikla offitu tóku 83\% beta-blokka fyrir aðgerð miðað við 68\% sjúklinga í kjörpyngd ( $p=0,002)$ en fyrir hina tvo LPS-flokkana var hlutfallið í kringum 71\%. Svipaða sögu var að segja um blóðfitulækkandi lyf. 50\% sjúklinga með mikla offitu tóku acetýlsalisýlsýru, sem var marktækt fleiri borið saman við aðra pyngdarhópa, eða 35\% með offitu, 39\% í ofpyngd og 29\% í kjörpyngd ( $<<0,001)$. Ekki var marktækur munur á töku heparins og clopidogrels milli hópanna.

Fjöldi fjartenginga á kransæðar var sambærilegur á milli allra hópanna, einnig hlutfall aðgerða sem framkvæmdar voru á sláandi hjarta (OPCAB) (Tafla II). Í sömu töflu sést að aðgerðartími var að meðaltali um 25 mínútum lengri hjá peim sem voru með mikla offitu miðað við kjörpyngd $(\mathrm{p}<0,001)$ en aðeins munaði 5 mínútum á tangartíma hjá pessum sömu hópum.

Tafla II sýnir samanburð á tíðni fylgikvilla á fyrstu 30 dögum eftir aðgerð, bæði minniháttar og alvarlegra. Hjá sjúklingum í kjörpyngd var tíðni skurðsýkinga $10 \%$ en tvöfalt hærri hjá sjúklingum með mikla offitu $(p=0,005)$. Sjúklingar með hærri LPS gengust marktækt sjaldnar undir aftöppun fleiðruvökva miðað við sjúklinga í kjörpyngd en tíðni nýtilkomins gáttatifs/-flökts og lungnabólgu var hins vegar sambærileg. Ekki sást heldur marktækur munur á tíðni alvarlegra fylgivkilla milli pyngdarflokka né heldur dánartíðni innan 30 daga frá aðgerð sem var $2 \%$ fyrir hópinn í heild.

Blæðing fyrstu 24 klst eftir aðgerð var sambærileg í hópunum en sjúklingar í kjörpyngd fengu oftar rauðkornapykkni en sjúklingar í ofpyngd og munaði 0,7 einingum $(p=0,009)$. Legutími á gjörgæslu var sambærilegur á milli hópanna fjögurra (tafla II) en sjúklingar í of pyngd höfðu tveimur dögum styttri heildarlegutíma en sjúklingar með mikla offitu ( $p=0,01)$.

Mynd 1a sýnir langtímalifun sjúklinga eftir aðgerð í LPS-hópunum fjórum. Lifun fyrir hópinn í heild var 97\% eftir 1 ár, 90\% eftir 5 ár og 73\% eftir 10 ár, og reyndist ekki marktækur munur milli LPS-hópa (log-rank próf, $\mathrm{p}=0,088$ ). Mynd 1b sýnir MACCEfría lifun sem einnig var sambærileg milli LPS-hópanna fjögurra 
Tafla IIla. Fjölpáttagreining á sjálfstæðum forspárpáttum dauða hjá sjúklingum sem gengust undir kransæðahjáveituaðgerð á Íslandi 2001-2013. Gefið er upp hættuhlutfall $(\mathrm{HH})$, 95\% öryggisbil og p-gildi fyrir hverja breytu fyrir sig. Marktækni miðast við $p<0,05$.

\begin{tabular}{lccc}
\hline Forspárpáttur & $\mathrm{HH}$ & $95 \%$ ÖB & p-gildi \\
\hline Sykursýki & 1,98 & $1,48-2,66$ & $<0,001$ \\
\hline Útfallsbrot vinstri slegils $<30 \%$ & 1,98 & $1,24-3,15$ & 0,004 \\
\hline Skert nýrnastarfsemi* & 1,93 & $1,40-2,66$ & $<0,001$ \\
\hline Langvinn lungnateppa & 1,65 & $1,13-2,40$ & 0,009 \\
\hline Útfallsbrot vinstri slegils $30-50 \%$ & 1,24 & $0,96-1,62$ & 0,1 \\
\hline EuroSCORE II & 1,07 & $1,03-1,11$ & $<0,001$ \\
\hline Hækkandi aldur & 1,07 & $1,05-1,09$ & $<0,001$ \\
\hline Aðgerðarár & 0,91 & $0,87-0,96$ & $<0,001$ \\
\hline Blóðfitulækkandi statín & 0,76 & $0,58-0,99$ & 0,044 \\
\hline Líkamspyngdarstuðull & 0,98 & $0,95-1,01$ & 0,87 \\
\hline${ }^{*}$ GSH<60 ml/mín/1,73 m² & & &
\end{tabular}

${ }^{*} \mathrm{GSH}<60 \mathrm{ml} / \mathrm{min} / 1,73 \mathrm{~m}^{2}$

Tafla Illb. Fjö/páttagreining á sjálfstæðum forspárpáttum MACCE (major adverse cardiac and cerebrovascular event) hjá sjúklingum sem gengust undir kransæðahjáveituaðgerð á Íslandi 2001-2013. Gefið er upp hættuhlutfall (HH), 95\% öryggisbil og p-gildi fyrir hverja breytu fyrir sig. Marktækni miðast við $p<$ 0,05 .

\begin{tabular}{lccc}
\hline Forspárpáttur & $\mathrm{HH}$ & $95 \%$ ÖB & p-gildi \\
\hline Útfallsbrot vinstri slegils $<30 \%$ & 1,89 & $1,27-2,79$ & 0,002 \\
\hline Kransæðapræðing með eða án stoðnets $^{\prime}$ & 1,79 & $1,36-2,35$ & $<0,001$ \\
\hline Skert nýrnastarfsemi $^{\star}$ & 1,53 & $1,17-2,00$ & 0,002 \\
\hline Langvinn lungnateppa $^{\prime}$ & 1,41 & $1,03-1,93$ & 0,034 \\
\hline Sykursýki & 1,35 & $1,06-1,72$ & 0,014 \\
\hline EuroSCORE II & 1,07 & $1,04-1,10$ & $<0,001$ \\
\hline Aldur & 1,03 & $1,02-1,04$ & $<0,001$ \\
\hline Aðgerðarár & 0,96 & $0,93-1,00$ & $<0,035$ \\
\hline Líkamspyngdarstuðull & 1 & $0,98-1,02$ & 0,95 \\
\hline
\end{tabular}

*GSH<60 ml/mín/1,73 m²

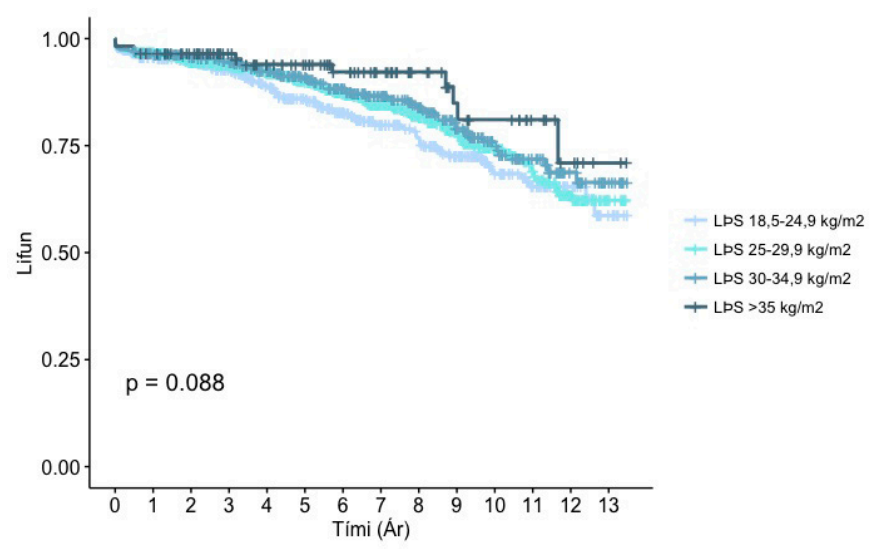

Mynd 1a. Kaplan-Meier kúrfur fyrir heildarlifun sjúklinga eftir LPS hópum. Ekki var marktækur munur á milli hópanna (log-rank próf, p=0,088).

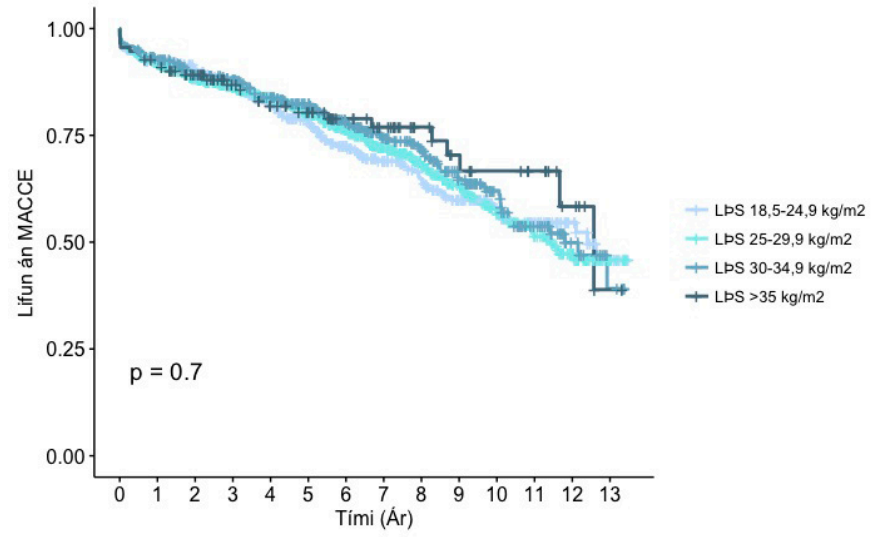

Mynd 1b. Kaplan-Meier kúrfur fyrir lifun án MACCE (major adverse cardiac and cerebrovascular event) eftir LPS hópum. Ekki var marktækur munur á milli hópanna (log-rank próf, $p=0,7$ ).

(log-rank próf $\mathrm{p}=0,7)$, en eftir 1 ár var hún 96\%, 80\% eftir 5 ár og $59 \%$ eftir 10 ár.

Fjölbreytugreining (Cox-aðhvarfsgreining) á helstu forspárpáttum dauða er sýnd í töflu IIIa en LPS var bæði notuð sem samfelld og flokkabreyta með svipuðum niðurstöðum. LPS reyndist ekki vera forspárpáttur dauða eftir að leiðrétt hafði verið fyrir fyrir öðrum páttum í líkaninu, en pað voru hins vegar sykursýki (HH: 1,98 95\% ÖB: 1,48-2,66), skert útfallsbrot vinstri slegils (<30\%) (HH: 1,98 95\% ÖB: 1,24-3,15), skert nýrnastarfsemi (HH: 1,93 95\% ÖB: 1,40-2,66), langvinn lungnateppa (HH: 1,65 95\% ÖB: 1,13-2,40), hærra EuroSCORE II (HH: 1,07 95\% ÖB: 1,03-1,11) og aldur (HH: 1,07 95\% ÖB: 1,05-1,09).

Í töflu IIIb sést Cox-aðhvarfsgreining fyrir sjálfstæða forspárpætti MACCE en við fjölbreytugreiningu reyndist LPS ekki vera forspárpáttur MACCE eftir að leiðrétt hafði verið fyrir öðrum páttum í líkaninu. Sterkustu sjálfstæðu forspárpættir MACCE voru skert útfallsbrot vinstri slegils (<30\%) (HH: 1,89 95\% ÖB: 1,272,79), saga um fyrri kransæðapræðingu með eða án ísetningar stoðnets (HH: 1,79 95\% ÖB: 1,36-2,35), skert nýrnastarfsemi fyrir aðgerð (HH: 1,53 95\% ÖB: 1,17-2,00), langvinn lungnateppa (HH: 1,42 95\% ÖB: 1,03-1,93), sykursýki (HH: 1,35 95\% ÖB: 1,06-1,72), hátt EuroSCORE II (HH: 1,07 95\% ÖB: 1,04-1,19) og aldur (HH: 1,03 95\% ÖB: 1,02-1,04). Loks reyndist aðgerðarár verndandi forspárpáttur fyrir MACCE en horfur vænkuðust eftir pví sem leið á tímabilið (HH: 0,96).

\section{Umræður}

Helstu niðurstöður pessarar rannsóknar voru að sjúklingum með offitu virðist vegna jafn vel og sjúklingum í kjörpyngd eftir kransæðahjáveitu, bæði fyrst eftir aðgerðina en einnig pegar til lengri tíma er litið. Sjúklingar með offitu og mikla offitu voru tveimur og sex árum yngri en peir í kjörpyngd, en pegar leiðrétt var fyrir aldri í fjölbreytugreiningu spáði LPS hvorki fyrir langtímalifun né MACCE-frírri lifun. Niðurstöðurnar benda pví til pess að aðrir pættir en líkamspyngdarstuðull vegi pyngra pegar 
kemur að langtímahorfum sjúklinga eftir kransæðahjáveitu. Svipuðum niðurstöðum hefur verið lýst erlendis. .4, 25, 27, $37^{2}$

Í heild var 30 daga dánartíðni $2 \%$, og var hún svipuð í öllum LPS-hópunum. Svipuðum niðurstöðum hefur verið lýst erlendis ${ }^{28,} 37-39$, enda pótt til séu rannsóknir sem sýna lægri dánartíðni sjúklinga með háan LPS. ${ }^{40,41}$ Í eldri rannsókn frá Landspítala, par sem aðeins var litið á 720 sjúklinga af peim 1698 sem hér er lýst og gengust undir kransæðaaðgerð á tímabilinu 2002-2006, var 30 daga dánarhlutfall sömuleiðis $2 \%{ }^{15}$

Athyglisvert er að aðeins tæpur fjórðungur sjúklinga voru í kjörpyngd en $77 \%$ í mismikilli ofpyngd, par af 7\% með mikla offitu. Skipting sjúklinga í LPS-flokka er ápekk peirri sem lýst var í breskri rannsókn ${ }^{28}$, en í mörgum erlendum rannsóknum er hlutfall sjúklinga með mikla offitu umtalsvert hærra, til dæmis var pað 38\% í tveimur bandarískum rannsóknum. ${ }^{41}{ }^{42}$ Sjúklingar með offitu höfðu marktækt fleiri áhættupætti kransæðasjúkdóms sem aftur eykur hættu á að peir prói með sér kransæðasjúkdóm snemma. Petta skýrir af hverju peir voru nokkrum árum yngri en sjúklingar í kjörpyngd og pví með lægra EuroSCORE II en aldur er mikilvæg breyta í áhættulíkaninu. ${ }^{25,40,43}$ Pannig hafði rúmlega priðjungur sjúklinga í mikilli ofpyngd sykursýki borið saman við einn af hverjum tíu í kjörpyngd. Erlendis er hlutfall sykursjúkra mun hærra, eða allt að $49 \%$ og $65 \%$ hjá sjúklingum með offitu og mikla offitu. ${ }^{44}$ Par, líkt og í okkar rannsókn, voru flestir sjúklinganna á töflumeðferð. ${ }^{42}$

Langtímalifun reyndist sambærileg í LPS-hópunum fjórum. petta bendir til pess að taka beri offitupversögninni með fyrirvara og samrýmist eldri rannsókn af Landspítala par sem langtímalifun sjúklinga með LPS yfir og undir $30 \mathrm{~kg} / \mathrm{m}^{2}$ var sambærileg. ${ }^{15}$ Eins og áður hefur komið fram hefur offitupversögnin aðallega byggst á skammtímaárangri pessara aðgerða og pær fáu rannsóknir sem hafa birst á langtímaárangri, hafa verið misvísandi. Del Prete og félagar báru saman sjúklinga með LPS $<30 \mathrm{~kg} / \mathrm{m}^{2}$ og $>30 \mathrm{~kg} / \mathrm{m}^{2}$ og reyndist langtímalifun sambærileg. ${ }^{41}$ Í tveimur öðrum rannsóknum sást hins vegar betri lifun hjá sjúklingum með hærri LPS ${ }^{25,37}$, og var hluti skýringarinnar rakinn til pess að offitusjúklingarnir væru yngri en peir sem voru í kjörpyngd. ${ }^{37,41,45}$ Slíkur aldursmunur sást einnig í okkar rannsókn, en pótt tilhneiging til betri lifunar hafi sést með hærri LPS var munurinn ekki pað mikill að hann næði pví að vera marktækur. Petta sást einnig í fjölbreytugreiningu en par spáði LPS ekki fyrir um lifun eftir að leiðrétt hafði verið fyrir öðrum áhættupáttum, ekki síst aldri. Ennfremur reyndist MACCE-frí lifun sambærileg fyrir LPS-hópana fjóra. Erlendis eru fáar rannsóknir sem hafa beinst að langtíma fylgikvillum hjá offitusjúklingum en Zittermann og félagar lýstu pó verri MACCEfrírri lifun hjá sjúklingum með mikla offitu (LPS > $\left.35 \mathrm{~kg} / \mathrm{m}^{2}\right) .^{25}$

Tíðni bæði minniháttar og alvarlegra fylgikvilla var mjög sambærileg í hópunum fjórum. Petta átti við um nýtilkomið gáttatif/-flökt, lungnabólgu og pvagfærasýkingar, en hins vegar var sjaldnar gerð aftöppun á fleiðruvökva hjá sjúklingum með offitu. Sjúklingar með offitu greindust einnig oftar með sýkingu í skurðsári eftir aðgerð, sem er í samræmi við fjölda annarra rannsókna. ${ }^{40,42,46}$ Skýringin gæti legið í lélegra blóðflæði í húðbeðsfitu sem aftur getur hægt á gróanda sára. Einnig getur lengri aðgerðartími sjúklinga með offitu aukið líkur á sýkingum líkt og hærri tíðni sykursýki. ${ }^{23}$

Pyngri sjúklingar fengu marktækt færri einingar af rauðkornapykkni en sjúklingar í kjörpyngd og munaði 0,7-1 einingum. Samt reyndist ekki marktækur munur á blæðingu í brjóstholskera í LPShópunum fjórum. Aðrar rannsóknir hafa sýnt marktækt minni blæðingu og gjöf rauðkornapykknis hjá sjúklingum í ofpyngd. ${ }^{42}$ Skýringin er ekki pekkt en settar hafa verið fram kenningar um að meiri fita í miðmæti og aukinn prýstingur í kviðarholinu geti prýst að hugsanlegum blæðingarstöðum í kringum hjartað og pannig stuðlað að betri blóðstorknun. ${ }^{20}$ Einnig er hugsanlegt að skurðlæknar sem framkvæma aðgerðir á offitusjúklinum séu reyndari, en ekki var litið sérstaklega á reynslu skurðlæknis í okkar rannsókn. Legutími var sambærilegur milli hópa, bæði á gjörgæslu og heildarlegutími á sjúkrahúsi. Рað eru sambærilegar niðurstöður og í tveimur erlendum rannsóknum. ${ }^{25,39}$ Skýringin á lengri legutíma sjúklinga með offitu hér á landi er ekki fyllilega ljós en tengist mögulega hærri tíðni skurðsýkinga hjá pessum hópi sjúklinga. ${ }^{47}$

Styrkur rannsóknarinnar er að hún nær til allra sjúklinga sem gengust undir kransæðahjáveituaðgerð hjá heilli pjóð á 13 ára tímabili. Nákvæmar upplýsingar um langtímalifun allra sjúklinga fengust úr dánarmeinaskrá Landlæknis en einungis purfti að sleppa 2,8\% sjúklinga vegna pess að mælingar á hæð og pyngd vantaði. Ennfremur er ótvíræður styrkleiki að hægt var að leita að langtíma fylgikvillum í sjúkraskrám sjúkrahúsa í öllum heilbrigðisumdæmum landsins og nota til pess miðlægar skrár. Veikleiki pessarar rannsóknar er hins vegar sú staðreynd að hún er afturskyggn og skráning upplýsinga á einkennum, áhættupáttum, faraldsfræðilegum páttum og fylgikvillum pví ekki jafn nákvæm og ef hún hefði verið framskyggn. LPS sem greiningaskilmerki fyrir offitu hefur sína annmarka, til dæmis greinir stuðullinn ekki á milli vöðva og fitu en er engu að síður pað mælitæki sem er talið hentugast og mest notað við rannsóknir eins og pessa. ${ }^{45}$ Loks má nefna að svokallaðir gruggunarpættir (unmeasured confounders) gætu haft áhrif á niðurstöðurnar og skýrt góðan árangur hjá sjúklingum með offitu pví sjúklingum með mikla áhættu gæti frekar hafa verið vísað í kransæðavíkkun.

Samantekið pá virðist sjúklingum í ofpyngd farnast álíka vel eftir kransæðaaðgerð á Íslandi og sjúklingum í kjörpyngd.

\section{pakkir}

Gunnhildur Jóhannesdóttir, fyrrum skrifstofustjóri á Landspítala fyrir aðstoð við gagnasöfnun. Rannsókin var styrkt af Rannsóknarsjóði Háskóla Íslands, Vísindasjóði Landspítala og Minningarsjóði Helgu Jónsdóttur og Sigurliða Kristjánssonar. 


\section{Heimildir}

1. Ford ES, Ajani UA, Croft JB, Critchley JA, Labarthe DR, Kottke TE, et al. Explaining the decrease in U.S. deaths from coronary disease, 1980-2000. N Engl J Med. 2007;356:2388-98

2. Thorsson B, Aspelund T, Harris TB, Launer LJ, Gudnason $\mathrm{V}$. [Trends in body weight and diabetes in forty years in Iceland]. Læknablaðið. 2009;95:259-66.

3. Mendis S. Global Status Report on non communicable diseases 2014. Geneva: World Health Organization; 2014.

4. Organization WH. Obesity, Preventing and Managing the Global Epidemic. Geneva: World Health Organization; 1997 3-5 June.

5. WHO. Noncommunicable Diseases Country Profiles 2014 Geneva: World Health Organization; 2014

6. Helgason T. Offita barna Læknablaðið. 2011;97:71.

7. Sigurðsson EL. Áhættupættir hjartasjúkdóma: Landlæknir; 2008 [updated 06.11.2008]. http://www. landlaeknir.is/um-embaettid/greinar/grein/item17741/ Ahaettuthaettir-hjartasjukdoma.

8. Yusuf S, Reddy S, Ounpuu S, Anand S. Global burden of cardiovascular diseases: part I: general considerations, the epidemiologic transition, risk factors, and impact of urbanization. Circulation. 2001;104(22):2746-53.

9. Bastien M, Poirier P, Lemieux I, Després J-P. Overview of Epidemiology and Contribution of Obesity to Cardiovascular Disease. Progress in Cardiovascular Diseases. 2014:56:369-81.

10. Hubert HB, Feinleib M, McNamara PM, Castelli WP. Obesity as an independent risk factor for cardiovascular disease: a 26-year follow-up of participants in the Framingham Heart Study. Circulation. 1983;67(5):968-77.

11. Whitlock G, Lewington S, Sherliker P, Clarke R, Emberson $\mathrm{J}$, Halsey J, et al. Body-mass index and cause-specific mortality in 900000 adults: collaborative analyses of 57 prospective studies. Lancet. 2009;373:1083-96.

12. Bastien M, Poirier P, Lemieux I, Despres JP. Overview of epidemiology and contribution of obesity to cardiovascular disease. Prog Cardiovasc Dis. 2014;56(4):369-81.

13. Guðbjartsson T. Kransæðahjáveituaðgerð. In: Porgeirsson G, Guðbjartsson T. Kransæðabókin; 2016:43-57.

14. Sousa-Uva M, Neumann FJ, Ahlsson A, Alfonso F, Banning AP, Benedetto U, et al. 2018 ESC/EACTS Guidelines on myocardial revascularization. Eur J card-thorac surg: official journal of the Eur Assoc for Card-thor Surg. 2019:55:4-90.

15. Oddsson SJ, Helgadóttir S, Sigurðsson MI, Viktorsson SA Arnórsson T, Guðbjartsson T. Tengsl offitu við árangur kransæðahjáveituaðgerða. Læknablaðið. 2011;97:223-8.

16. Choban Md FPS, Flancbaum Md FL. The Impact of Obesity on Surgical Outcomes: A Review. J Am Coll of Surg. 1997;185:593-603.

17. Gendall KA, Raniga S, Kennedy R, Frizelle FA. The impact of obesity on outcome after major colorectal surgery. Diseases of the colon and rectum. 2007;50:2223-37.

18. Gaujoux S, Torres J, Olson S, Winston C, Gonen M, Brennan MF, et al. Impact of obesity and body fat distribution on survival after pancreaticoduodenectomy for pancreatic adenocarcinoma. Ann surg oncol. 2012;19:2908-16

19. Johnson Iii ON, Sidawy AN, Scanlon JM, Walcott R, Arora S, Macsata RA, et al. Impact of Obesity on Outcomes after Open Surgical and Endovascular Abdominal Aortic Aneurysm Repair. J Am Coll of Surg. 2010;210:166-77.
20. Valentijn TM, Galal W, Tjeertes EK, Hoeks SE, Verhagen HJ, Stolker RJ. The obesity paradox in the surgical population. The surgeon: J Royal Coll Surg of Edinburgh and Ireland. 2013;11:169-76.

21. Stamou SC, Nussbaum M, Stiegel RM, Reames MK, Skipper ER, Robicsek F, et al. Effect of body mass index on outcomes after cardiac surgery: is there an obesity paradox? Ann Thorac Surg. 2011;91:42-7.

22. Sood A, Abdollah F, Sammon JD, Majumder K, Schmi $\mathrm{M}$, Peabody JO, et al. The Effect of Body Mass Index on Perioperative Outcomes After Major Surgery: Results from the National Surgical Quality Improvement Program (ACS-NSQIP) 2005-2011. World journal of surgery. (ACS-NSQIP) 2015:39:2376-85.

23. Tjeertes EK, Hoeks SE, Beks SB, Valentijn TM, Hoofwijk AG, Stolker RJ. Obesity--a risk factor for postoperative complications in general surgery? BMC anesthesiology. 2015;15:112.

24. Ao H, Wang X, Xu F, Zheng Z, Chen M, Li L, et al. The Impact of Body Mass Index on Short- and Long-Term Outcomes in Patients Undergoing Coronary Artery Graft Bypass. PLoS ONE. 2014;9:e95223.

25. Zittermann A, Becker T, Gummert JF, Börgermann J. Body mass index, cardiac surgery and clinical outcome. A single-center experience with 9125 patients. Nutrition, Metabolism and Cardiovascular Diseases. 2014:24:168-75.

26. Efros LA, Samorodskaya IV. [Survival of Overweigh Patients After Coronary Artery Bypass Surgery. Does the „Obesity Paradox" Play a Role?]. Kardiologiia. 2015;55:45 50.

27. Hallberg V, Kataja M, Lahtela J, Tarkka M, Inamaa T, Palomaki A. Obesity paradox disappears in coronary artery bypass graft patients during 20-year follow-up. artery bypass graft patients during 20-year follow-up. European

28. Benedetto U, Danese C, Codispoti M. Obesity paradox in coronary artery bypass grafting: myth or reality? J Thora Cardiovasc Surg. 2014;147:1517-23

29. Kuduvalli M, Grayson AD, Oo AY, Fabri BM, Rashid A. The effect of obesity on mid-term survival following coronary artery bypass surgery. Eur J card-thorac surg. official journal of the Eur Assoc for card-thorac Surg 2003;23:368-73.

30. WHO. BMI classification 2006 [updated 12.05.2017. Available from: http://apps.who.int/bmi/index.jsp?introPage=intro $3 . \mathrm{html}$

31. NK Foundation. NKF K/DOQI Guidelines: Clinical Practice Guidelines and Clinical Practice Recommendations. 2006.

32. Campeau L. The Canadian Cardiovascular Society grading of angina pectoris revisited 30 years later. Can Cardiol. 2002;18:371-9.

33. Kubo SH, Schulman S, Starling RC, Jessup M, Wentworth D, Burkhoff D. Development and validation of a patien questionnaire to determine New York Heart Association classification. Journal of cardiac failure. 2004;10:228-35.

34. Noyez L, Kievit PC, van Swieten HA, de Boer MJ. Cardia operative risk evaluation: The EuroSCORE II, does it make a real difference? Netherlands heart journal : J Netherlands Soc of Cardiol and the Netherlands Heart Foundation. 2012;20:494-8.

35. ISo Nephrology. Kidney disease: Improving global outcomes. 2012
36. Mohr FW, Morice MC, Kappetein AP, Feldman TE, Stahle E, Colombo A, et al. Coronary artery bypass graft surgery versus percutaneous coronary intervention in patients with three-vessel disease and left main coronary disease: 5-year follow-up of the randomised, clinical SYNTAX trial. Lancet. 2013:381:629-38.

37. Del Prete JC, Bakaeen FG, Dao TK, Huh J, LeMaire SA, Coselli JS, et al. The Impact of Obesity on Long-term Survival After Coronary Artery Bypass Grafting1. Journal of Surgical Research. 2010;163:7-11.

38. Protopapas AD. Does Body Mass Index Affect Mortality in Coronary Surgery? The open cardiovascular medicine journal. 2016;10:240-5.

39. Lopez-Delgado JC, Esteve F, Manez R, Torrado H, Carrio $\mathrm{ML}$, Rodríguez-Castro D, et al. The Influence of Body Mass Index on Outcomes in Patients Undergoing Cardiac Surgery: Does the Obesity Paradox Really Exist? PLoS ONE. 2015;10:e118858.

40. Mariscalco G, Woźniak MJ, Dawson AG, Serraino GF, Porter $\mathrm{R}$, Nath $\mathrm{M}$, et al. Body-Mass Index and Mortality Among Adults Undergoing Cardiac Surgery:A Nationwide Study with a Systematic Review and MetaAnalysis. Circulation. 2017;135:850-63

41. Stamou SC, Nussbaum M, Stiegel RM, Reames MK, Skipper ER, Robicsek F, et al. Effect of Body Mass Index on Outcomes After Cardiac Surgery: Is There an Obesity Paradox? The Annals of Thoracic Surgery. 2011:91:42-7.

42. Alam M, Siddiqui S, Lee V-V, Elayda MA, Nambi V, Yang EY, et al. Isolated Coronary Artery Bypass Grafting in Obese Individuals: A Propensity Matched Analysis of Outcomes. Circulation Journal. 2011;75:1378-85.

43. Finucane MM, Stevens GA, Cowan MJ, Danaei G, Lin JK, Paciorek CJ, et al. National, regional, and global trends in body-mass index since 1980: systematic analysis of health examination surveys and epidemiological studies with 960 country-years and 9.1 million participants. Lancet. 2011;377:557-67.

44. Devarajan J, Vydyanathan A, You J, Xu M, Sessler DI, Sabik JF, et al. The association between body mass index and outcome after coronary artery bypass grafting operations. Eur J card-thorac surg: official journal of the Eur Assoc for card-thorac Surg. 2016;50:344-9.

45. Romero-Corral A, Montori VM, Somers VK, Korinek J, Thomas RJ, Allison TG, et al. Association of bodyweight with total mortality and with cardiovascular events in coronary artery disease: a systematic review of cohort studies. Lancet 2006:368:666-78.

46. Prabhakar G, Haan CK, Peterson ED, Coombs LP, Cruzzavala JL, Murray GF. The risks of moderate and extreme obesity for coronary artery bypass grafting outcomes: a study from the Society of Thoracic Surgeons database. Ann Thorac Surg. 2002;74:1125-30; discussion 30-1.

47. Coskun D, Aytac J, Aydinli A, Bayer A. Mortality rate, length of stay and extra cost of sternal surgical site infections following coronary artery bypass grafting in a private medical centre in Turkey. J Hosp Infect. 2005;60:176-9. 


\section{No significant association between obesity and long-term outcome of coronary artery bypass grafting}

\section{Thorkelsdottir $\mathrm{T}^{1}$ \\ Johannesdottir $\mathrm{H}^{2}$ \\ Arnadottir LO ${ }^{2}$ \\ Adalsteinsson $\mathrm{J}^{6}$ \\ Gardarsdottir $\mathrm{HR}^{3}$ \\ Helgason $D^{3}$ \\ Axelsson $\mathrm{TA}^{2}$ \\ Helgadottir $\mathrm{S}^{5}$ \\ Heimisdottir $\mathrm{A}^{1}$ \\ Sigurdsson Ml,1,4 \\ Gudbjartsson $\mathrm{T}^{1,2}$}

Objectives: Our objective was to investigate long-term outcomes of obese patients undergoing coronary artery bypass grafting (CABG) in Iceland.

Materials and methods: $A$ retrospective analysis on 1698 patients that underwent isolated CABG in Iceland between 2001-2013. Patients were divided into four groups according to body mass index (BMI); Normal=18.5-24.9kg/m² ( $\mathrm{n}=393)$, ii) overweight=25-29.9 kg/ $\mathrm{m}^{2}(\mathrm{n}=811)$, iii) obese $=30-34.9 \mathrm{~kg} / \mathrm{m}^{2}(\mathrm{n}=388)$ and iv) severely obese $\geq 35 \mathrm{~kg} / \mathrm{m}^{2}$ ( $\left.\mathrm{n}=113\right)$. Thirty-day mortality and short-term complications were documented as well as long-term complications that were pooled into major adverse cardiac and cerebrovascular events (MACCE) and included myocardial infarction, stroke, repeated CABG, percutaneous coronary intervention with or without stenting, and death. After pooling the study groups, survival and freedom from MACCE plots (KaplanMeier) were generated and Cox regression analysis used to identify predictive factors of survival. Average follow-up time was 5.6 years. Results: Severely obese and obese patients were significantly younger than those with a normal BMI, more often males with identifiable risk factors of coronary artery disease (CAD) and a lower EuroSCORE II (1.6 vs. 2.7, $p=0.002)$. The incidence of major early complications, 30 -day mortality (2\%), long-term survival $(90 \%$ at 5 years, log-rank test $p=0.088)$ and MACCE-free survival $(81 \%$ at 5 years, log-rank test $\mathrm{p}=0.7$ ) was similar for obese and non-obese patients. BMI was neither an independent predictor for long-term (OR: 0.98 95\%-Cl: 0.95-1.01) nor MACCE-free survival (OR: 1.0 95\%-Cl: 0.98-1.02).

Conclusions: Obese patients that undergo CABG in Iceland are younger and have an increased number of risk factors for coronary disease when compared to non-obese patients. However, BMI neither predicted long-term survival or long-term complications. The outcomes following CABG in obese patients are good in Iceland.

${ }^{1}$ Faculty of Medicine, University of Iceland, Departments of ${ }^{2}$ Cardiothoracic Surgery, ${ }^{3}$ Internal Medicine and ${ }^{4}$ Anaesthesia and Intensive Care, Landspitali University Hospital, ${ }^{5}$ Department of Anaesthesia and Intensive Care, Akademiska University Hospital, Uppsala, Sweden. ${ }^{6}$ Department of Internal medicine and Dermatology, University of Connecticut, Conneticut, USA

Key words: $C A B G$, obesity, complications, long-term, MACCE, survival

Correspondence: Tómas Guð̋jartsson tomasgudbjartsson@hotmail.com 